\title{
HUBUNGAN STATUS GIZI IBU HAMIL DENGAN BAYI BERAT BADAN LAHIR RENDAH ( BBLR ) DI RSUD GAMBIRAN KOTA KEDIRI
}

Lely Khulafa'ur R. ${ }^{1}$ Betristasia P. ${ }^{2}$ Ridhatul Amnah ${ }^{3}$ Akademi Kebidanan Dharma Husada Kediri

\begin{abstract}
ABSTRAK
Gizi adalah makanan dan zat gizi dalam makanan yang berguna bagi kesehatan.BBLRialah bayi baru lahir yang berat badannya saat lahir kurang dari 2500 gram.Faktor dari BBLR salah satunya ialah status gizi ibu. Tujuan dilakukan penelitian ini adalah Mengetahui hubungan status gizi ibu hamil dengan bayi berat badan lahir rendah diRSUD Gambiran Kota Kediri.

Desain penelitian yang digunakan adalah analitik korelasi dengan pendekatan Retospektif Study. Populasi penelitian ini adalah data rekam medis semua yang melahirkan dengan BBLR di RSUD Gambiran Kota Kediri bulanJanuari Marettahun 2015 dengan jumlah 31 responden.Dengan teknik puposive sampling didapatkan 25 responden. Variabel dalam penelitian ini terdapat dua variabel yaitu variabel independen dan dependen. Variabel independen yaitu status gizi ibu hamil dan variabel dependennya bayi berat badan lahir rendah. Pengumpulan data menggunakan Buku Rekam Medik yang dilakukan pada 17 mei 2015.Pengolahan data menggunakan editing, coding, scoring, tabulating.Dengan analisa data Spearman Rank.

Hasil penelitian menunjukkan bahwa dari 25 responden, mayoritas responden mempunyai status gizi normal yaitu 10 responden (40\%), sedangkan kejadian bayi lahir dengan berat badan lahir rendah, sebagian besar masuk dalam kategori BBLR (1500-2500 gram) dengan jumlah 23 bayi (92\%). Hasil uji statistika dengan korelasi Spearman Rank, Kesimpulannya $\mathrm{p}=-0,186<0,396$, maka H1 ditolak dan Ho diterima.

Berdasarkan hasil penelitian maka dapat disimpulkan tidak ada hubungan status gizi ibu dengan BBLR.Maka dibutuhkan peran tenaga kesehatan untuk melakukan penyuluhan dan pemantauan ANC untuk menekan kejadian BBLR.
\end{abstract}

\section{Kata Kunci: Hubungan Status Gizi Ibu Hamil, BBLR}




\section{PENDAHULUAN}

Keberhasilan pembangunan kesehatan salah satunya dapat dinilai dari indikator derajat kesehatan masyarakat antara lain Angka Kematian Ibu (AKI) dan Angka Kematian Bayi (AKB).Masalah kematian ibu dan bayi merupakan masalah yang harus mendapat perhatian lebih dan serius.

Keadaan gizi ibu sebelum dan selama hamil mempengaruhi status gizi ibu dan bayi. Pertumbuhan dan perkembangan janin sangat dipengaruhi oleh asupan gi . ibu,karena kebutuhan gizi janin beras dari ibu. Ibu hamil membutuhkan asupan gizi yang cukup untuk dirinya dan bayi yang dikandungnya. Pemantauan status gizi ibu hamil dapat dilakukan dengan melihat penambahan berat badan selama kehamilan. Kenaikan berat badan bisa dijadikan indikator kesehatan ibu dan juga janinnya. Laju pertambahan berat badan selama kehamilan merupakan petunjuk yang sama pentingnya dengan pertambahan berat itu sendiri. Oleh karena itu sebaiknya ditentukan patokan besaran pertambahan berat sampai kehamilan berakhir, sekaligus serta memantau prosesnya dan dituliskan dalam Kartu Menuju Sehat (KMS) ibu hamil. Pemantauan yang sering dilakukan dengan pemeriksaan antoprometri yaitu dengan melakukan penimbangan berat badan, pengukuran tinggi badan, dan penentuan berat badan ideal serta pola pertambahan berat. Upaya pemantauan status gizi ibu selama hamil memerlukan data berat badan sebelum hamil serta berat badan pada kunjungan pertama. Berat badan sekarang diperlukan untuk penentuan pola pertambahan berat badan ibu hamil. Hal ini sangat diperlukan sebagai pertimbangan prognosis serta perlu tidaknya intervensi gizi (Sulistyoningsih, 2012:109).

Bila ibu mengalami kekurangan gizi selama hamil akan menimbulkan masalah, baik pada ibu maupun janin. Gizi kurang pada ibu hamil dapat menyebabkan resiko dan komplikasi pada ibu antara lain: anemia, perdarahan, berat badan ibu tidak bertambah secara normal, dan terkena nyakit infeksi. Pengaruh gizi kurang hadap persalinan dapat mengakibatkan persalinan sulit dan lama, persalinan sebelum waktunya (premature), perdarahan setelah persalinan, serta persalinan dengan oprasi cenderung meningka (Kristiyanasari, 2010: 65-66).

Perempuan yang mengalami kekurangan gizi sebelum hamil atau selama minggu pertama kehamilan memiliki resiko lebih tinggi melahirkan bayi yang mengalami kerusakan otak dan sumsum tulang karena pembentukan sistem saraf sangat peka pada 2-5 minggu pertama. Ketika seorang perempuan mengalami kekurangan gizi pada trimester terakhir maka cenderung akan melahirkan bayi dengan berat badan lahir rendah (kurang dari 2500 gram),hal ini dikarenakan pada masa ini janin akan tumbuh dengan sangat cepat dan terjadi penimbunan jaringan lemak(Sulistyoningsih,2012: 108).

Status gizi ibu sebelum kehamilan sangat mempengaruhi pertumbuhan janin dalamkandungan, bila status gizi ibu baik pada sebelum hamil maka akan melahirkan bayiyang sehat, cukup bulan dengan berat badan 
normal. Kualitas bayi yang keadaan gizi ibu.

dilahirkansangat tergantung pada

\section{METODE}

Desain penelitian ini menggunakan analitik korelasional dengan menggunakan pendekatan "Retrospektif study".Populasi penelitian ini adalah data rekam medis semua yang melahirkan dengan BBLR di RSUD Gambiran Kota Kediri bulanJanuari Marettahun 2015 dengan jumlah 31 responden.Dengan teknik puposive sampling didapatkan 25 responden.Variabel dalam penelitian ini terdapat dua variabel yaitu

variabel independen dan dependen.Variabel independen yaitu status gizi ibu hamil dan variabel dependennya bayi berat badan lahir rendah. Pengumpulan data menggunakan Buku Rekam Mer ${ }_{2}$ yang dilakukan pada $17 \mathrm{n}^{2}$ 2015.Pengolahan data menggunakan editing, coding, scoring, tabulating.Dengan analisa data Spearman Rank.

\section{HASIL PENELITIAN}

\section{A. Data Umum}

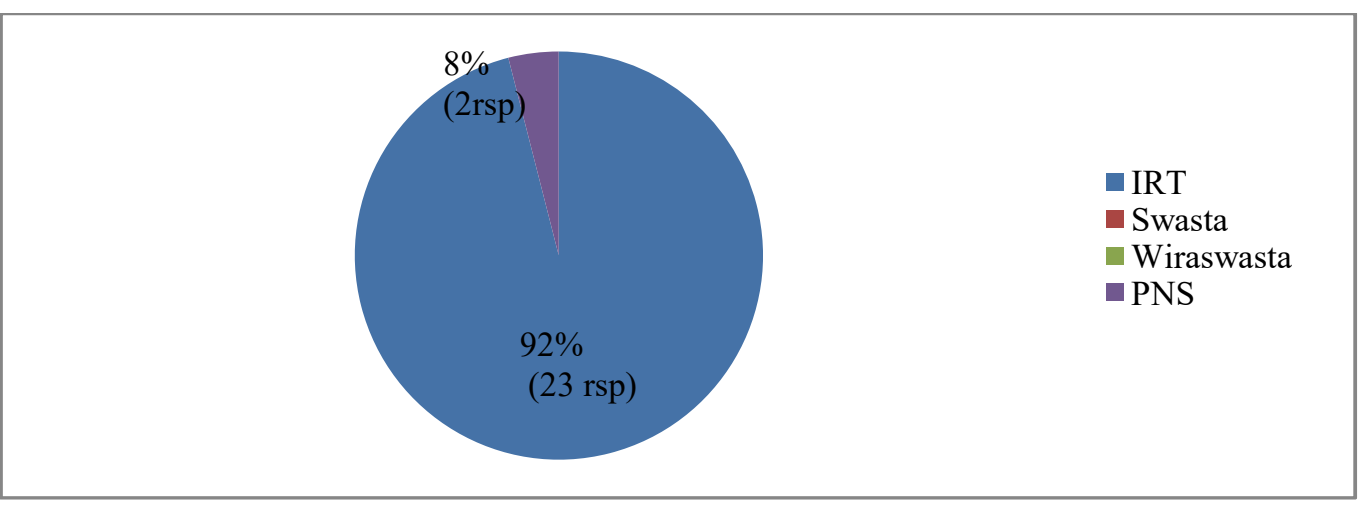
Diagram 1 Karakteristik Responden menurut Pekerjaan Ibu Responden di RSUD Gambiran Kota Kediri Bulan Januari - Maret tahun 2015




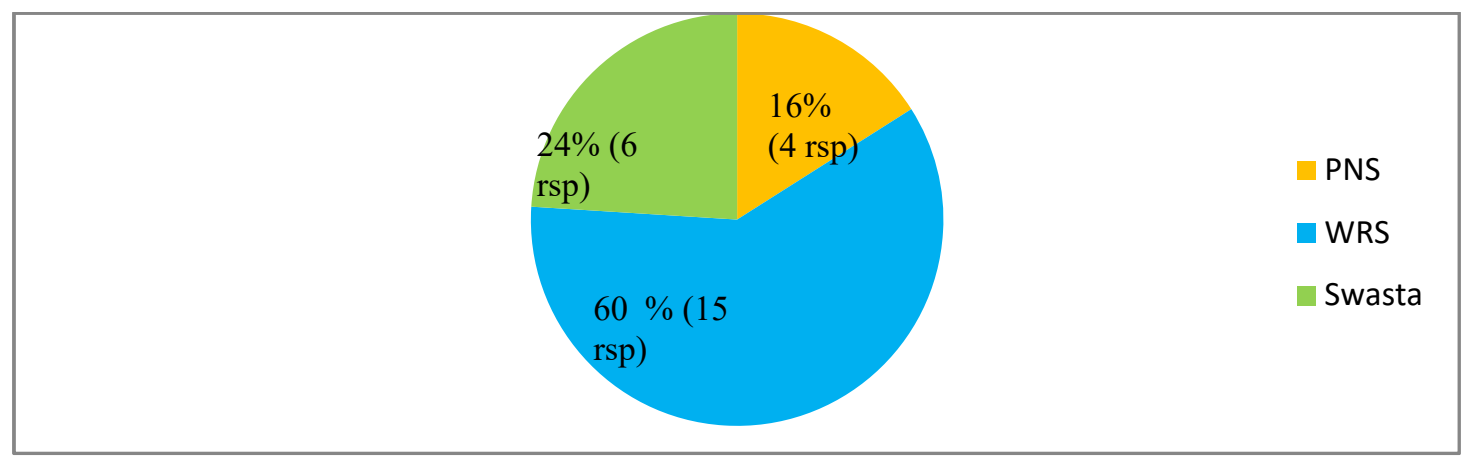

Diagram 2 Karakteristik Responden menurut Pekerjaan Suami Responden di RSUD Gambiran Kota Kediri Bulan Januari - Maret tahun 2015

Tabel 1. Tabulasi Silang Hubungan Status Gizi Ibu Hamil dengan Bayi Berat Badan Lahir Rendah di RSUD Gambiran Kota Kediri Bulan Januari - Maret tahun 2015

\begin{tabular}{ccccccccc} 
& \multicolumn{7}{c}{ Kejadian BBLR } & \\
\cline { 2 - 7 } Status Gizi Ibu & BBLR & $\%$ & BBLSR & $\%$ & BBLSAR & $\%$ & Jumlah & $\%$ \\
\hline Kurus & 8 & 32 & 0 & 0 & 0 & 0 & 8 & 32 \\
\hline Normal & 9 & 36 & 0 & 0 & 1 & 4 & 10 & 40 \\
\hline Lebih & 4 & 16 & 0 & 0 & 0 & 0 & 4 & 16 \\
\hline Obesitas & 2 & 8 & 0 & 0 & 1 & 4 & 3 & 12 \\
\hline Jumlah & 23 & 92 & 0 & 0 & 2 & 8 & 25 & 100
\end{tabular}

Berdasarkan tabel 1 dapat diketahui bahwa dari 25 responden, kejadian BBLR mayoritas terjadi

pada ibu yang mempunyai status gizi normal yaitu sejumlah 10 responden $(40 \%)$. Dari hasil

analisa dengan spearmen rank didapatkan rshitung $(-0,186)<$ rstabel $(0,396)$ maka Ho

diterima. Tidak ada hubungan antara status gizi dengan kejadian bayi berat badan lahir rendah,

\section{PEMBAHASAN}

Berdasarkan hasil uji statistika dengan korelasi Spearman Rank, didapatkan angka probabilitas rs hitung $(-0,186)<$ rs tabel $(0,396)$, maka H1 ditolak dan H0 diterima, hal ini menunjukkan tidak ada hubungan antara status gizi ibu hamil dengan bayi dengan berat badan lahir rendah.
Jika dilihat dari variabel bebas diatas, mayoritas responden mempunyai status gizi normal yaitu sebanyak 10 responden (40\%), dan minoritas responden mempunyai status gizi obesitas yaitu sebanyak 2 responden (8\%). Dan pada variabel terikat, sebagian besar ibu melahirkan bayi dengan berat badan lahir rendah 
(1500-2500 gr) yaitu sebanyak 23 responden $(92 \%)$, dan sisanya ibu melahirkan bayi dengan berat badan lahir amat sangat rendah yaitu sebanyak 2 responden (8\%). Penyebab terbanyak terjadinya BBLR adalah kelahiran prematur. Faktor-faktor yang mempengaruhi bayi berat badan lahir rendah antara lain : faktor ibu (Toksemia gravidarum, perdarahan antepartum, trauma fisik dan psikologis, nefritis akut, diabetes militus, riwayat kelahiran prematur sebelumnya, perdarahan antepartum, malnutrisi, hidramnion, usia, jarak kehamilan, dll). Faktor janin (ada beberapa faktor dari janin yang mempengaruhi kelahiran bayi berat badan lahir rendah antara lain : (hidramnion, kehamilan ganda, kelainan kromosom, ketuban pecah dini). Faktor lain (selain faktor ibu dan janin, terdapat juga faktor lain yaitu : faktor plasenta : plasenta previa, solusio plasenta; faktor lingkungan, tempat tinggal dataran tinggi, radiasi, zat-zat racun; kebiasaan: ibu perokok, peminum alkohol, pecandu narkotik, pekerjaan yang melelahkan) (Pantiawati, 2010: 4-5).

Bayi dengan berat badan lahir rendah tidak banyak yang disebabkan oleh status gizi ibu yang buruk, banyak faktor yang mempengaruhi bayi lahir dengan berat badan lahir rendah.

Dari berbagai responden tidak semua bayi berat lahir rendah dilahirkan oleh ibu dengan status gizi yang kurang.Dari penelitian yang didapatkan oleh peneliti mayoritas bayi berat badan lahir rendah dilahirkan oleh ibu dengan status gizi yang normal.Ada juga ibu yang mempunyai status gizi yang lebih dan obesitas melahirkan bayi dengan berat badan lahir rendah.Setelah diteliti dari beberapa responden yang melahirkan bayi dengan berat badan lahir rendah faktor terbanyak terjadinya kelahiran bayi dengan berat badan lahir rendah dikarenakan oleh preeklamsi.

Preeklamsia/ eklamsia dapat mengakibatkan keterlambatan pertumbuhan janin dalam kandungan atatu IUGR dan kelahiran mati hal ini disebabkan karena preeklamsia / eklamsia pada ibu akan menyebabkan perkapuran di daerah plasenta, sedangkan bayi memperoleh oksigen dan makanan dari plasenta, dengan adanya perkapuran di daerah plasenta, suplai makanan dan oksigen dari plasenta, yang masuk ke janin berkurang (Ilyas, 1999).

Preeklamsi dapat menyebabkan kelahiran dengan berat badan lahir rendah karena janin yang di dalam uterus tidak berkembang dengan baik.Hal ini disebabkan daerah disekitar plasenta mengalami pengapuran sehingga plasenta tidak dapat berfungsi dengan sempurna.Maka dari itu suplai makanan yang ditransfer dari ibu ke janin mengalami penghambatan dan menyebabkan janin tidak tumbuh dan berkembang dengan sempurna.

Selain itu ibu yang mengalami preeklamsia atau eklamsia juga dapat terjadi kejang, kejang dapat membahayakan ibu dan janin karena ibu susah untuk bernafas dan janin juga tidak mendapatkan suplai oksigen dari ibu. Maka dari itu ibu yang mengalami preeklamsia berat atau eklamsi harus dilakukan terminasi. Terminasi dilakukan tidak memandang usia kehamilannya, terminasi yang dilakukan pada usia kehamilan yang belum aterm. Pada keadaan ini janin yang berada di dalam kandungan belum tumbuh dan berkembang dengan 
sempurna, maka ketika dilakukan terminasi bayi lahir dengan berat badan lahir rendah karena prematur.

Menurut peneliti, status gizi ibu tidak berhubungan dengan terjadinya bayi lahir dengan berat badan lahir rendah.Karena tidak semua ibu hamil dengan status gizi yang kurang melahirkan bayi dengan berat badan lahir rendah, dan tidak semua ibu yang mempunyai status gizi cukup, lebih, bahkan obesitas dapat melahirkan bayi dengan berat badan lahir normal (diatas 2500 gr).Maka dari itu sangat diperlukan peran dari tenaga kesehatan untuk memberikan penyuluhan tentang faktor penyebab terjadinya bayi lahir dengan berat badan lahir rendah.

Dari faktor pekerjaan suami, dari 25 responden mayoritas bekerja sebagai wiraswasta sebanyak 15 responden $(60 \%)$ dan minoritas responden bekerja sebagai PNS sebanyak 4 responden (16\%).

Menurut Persatuan Ahli Gizi Indonesia (1999) yang dikutip oleh Supariasa, et al. (2002, p.13) adapun faktor-faktor yang dapat mempengaruhi status gizi ibu hamil, diantaranya adalah faktor langsung (asupan makanan atau pola konsurdan infeksi) dan faktor tidak langsı 5 (sosial ekonomi yang meliputi pendapatan keluarga).

Dari berbagai faktor pekerjaan suami juga sangat berpengaruh pada status gizi ibu hamil.Karena pekerjaan suami menentukan status ekonomi keluarga dan status ekonomi juga dapat mempengaruhi status gizi pada ibu.Pada penelitian didapatkan salah satu anggota keluarga keseluruhan mempunyai pekerjaan, sehingga status ekonomi tercukupi dan status gizinya terpenuhi dengan baik.Hal ini tidak berpengaruh pada kelahiran bayi dengan berat badan lahir rendah, karena mayoritas bayi yang lahir dengan berat badan lahir rendah dilahirkan oleh ibu yang mempunyai status gizi yang normal.

Dilihat dari faktor pendidikan, dari 25 responden mayoritas responden berpendidikan SMA sebanyak 12 responden $(48 \%)$.

Pendidikan adalah pembelajaran pengetahuan, ketrampilan, dan kebiasaan sekelompok orang yang diturunkan dari satu generasi ke generasi berikutnya melalui pengajaran, pelatihan atau penelitian (KBBI).

Pendidikan ibu yang sebagian besar adalah SMA tidak mempengaruhi terjadinya kelahiran dengan berat badan lahir rendah, karena pendidikan SMA termasuk pendidikan yang cukup untuk mendapatkan pengetahuan tentang gizi.Pada ibu yang mempunyai status gizi yang cukup dapat dengan mudah megerti tentang pengetahuan yang diberikan oleh tenaga kesehatan seperti pada saat ibu melakukan pemeriksaan kehamilan ibu lebih mudah memahami maksud dari informasi yang diberikan sehingga ibu tapat menerapkannya pada zesehariannya.Asupan gizi dari ibu ke bayinya dapat terpenuhi dengan sempurna dan ibu melahirkan bayidengan berat badan yang normal.

Semakin banyak ibu berpendidikan tinggi juga dapat berpengaruh untuk mengurangi terjadinya status gizi kurang sehingga status gizi ibu terpenuhi dan asupan gizi dari ibu yang ditransfer ke janin sempurna.Hal ini dapat mengurangi terjadinya bayi lahir dengan berat badan lahir rendah. 


\section{Simpulan}

Berdasarkan hasil penelitian dan analisa data yang dilakukan maka dapat ditarik kesimpulanTidak ada hubungan antara status gizi dengan kejadian bayi berat badan lahir rendah.Bagi Pembaca

\section{Saran}

Hasil penelitian ini diharapkan dapat dijadikan sebagai masukan dan menambah referensi dibidang kesehatan khususnya dalam pemenuhan gizi selama hamil agar dapat membantu kenaikan berat badan ibu sesuai dengan usia kehamilan

\section{DAFTAR PUSTAKA}

Sulistyoningsih, Haryani. 2012. Gizi untuk Kesehatan Ibu Dan Anak. Yogyakarta: Graha Ilmu

Kristiyanasari, Weni. 2002. Gizi Ibu Hamil. Yogyakarta: Graha Medika

Pantiawati, Ika. 2010. Bayi dengan BBLR. Yogyakarta: Nuha Medika

Maryunani, dan Nurhayati.2009. Asuhan Kegawatdaruratan dan Penyulit Pada Neonatus. Jakarta: Trans Info Media
Supariasa, Bachyar dan Ibnu.20 6 Penilaian Status Gizi. Buku Kedokteran EGC

Istiyany, dan Rusilanti. 2014. Gizi Terapan. Bandung: PT Remaja Rosdakarya

Rukiyah, a dan Yulianti, L. 2012.Asuhan Neonatus. YPB-SP

Nursalam, 2008.Konsep Kebidanan Metode Penelitian Ilmu Keperawatan. Jakarta; Salemba Medika

Proverawati, dan Ismawati. 2010. BBLR Berat Badan Lahir Rendah. Yogyakarta: Nuha Medika 